\title{
軸方向に任意の載荷履歴を受ける鋼材の塑性変形能力 PLASTIC DEFORMATION CAPACITY OF STRUCTURAL STEEL UNDER VARIOUS AXIAL STRAIN HISTORIES
}

\author{
山田哲*1, 焦瑜*2, 吉敷祥一*3, 柴田篤宏*4 \\ Satoshi YAMADA, Yu JIAO, Shoichi KISHIKI \\ and Atsuhiro SHIBATA
}

\begin{abstract}
In the field of energy based seismic design, the structural performance of steel structures is determined by the energy dissipation capacity, which depends greatly on the plastic deformation capacity of the structural components that form the whole system. The plastic strain capacity of the structural steel is one of the primary factors that determine the components' plastic deformation capacity. Most of the cyclic loadings employed in the structural steel tests are the recommended standard (typically incremental or constant amplitude) loading protocols, which is insufficient to study the deformation capacity under random loadings such as earthquake effects. This paper focuses on the evaluation of the plastic strain capacity of structural steel under various axial strain histories till ductile fracture. A series of element specimens made of SS400 and SN400 steel were tested under diverse cyclic axial strain loadings. The deformation capacity of the structural steel under cyclic axial loading till fracture was evaluated by studying the experimental strain capacity/energy dissipation capacity of the skeleton curve and the Bauschinger part. The error range of this method was proved smaller than that of the Miner's rules.
\end{abstract}

Keywords: steel, loading pattern, deformation capacity, skeleton curve, Bauschinger effect 鋼材, 載荷履歴, 塑性変形能力, 骨格曲線, バウシンガー効果

\section{1. 序}

鋼構造建築の耐震性能は、構成部材の塑性変形能力に基づきエネ ルギー吸収能力として捉えることができる ${ }^{1,2)}$ 。構成部材の塑性変 形能力は、局部座屈や横座屈といった圧縮応力下での限界性能によ って決まる場合と、引張応力下での限界性能である破断によって決 まる場合に大別できる。このうち破断については、材料の勒性が不 足しているような場合には脆性的な破壊によって決まることがあ り、兵庫県南部地震では多くの被害が発生したことで原因究明や脆 性破壊回避のための研究が行われてきたが 3) 5)厷文、脆性的な破壊が 回避できたとしても、延性的な伸び能力や疲労寿命によって決まる 塑性変形能力の限界に至れば破断する。

鋼材や鋼部材の塑性変形能力に関寸る研究はこれまでも数多く行 われているが、その多くは鋼材としての変形性能、部材としての変 形性能を個々に検討したものであり、鋼材の変形性能から骨組の耐 震性能評価までを結びつけた研究は少ない。また、これまで行われ てきた鋼材や鋼部材の塑性変形能力に関する実験は定振幅載荷や漸 増振幅載荷に代表される標準的な載荷履歴で行われたものがほとん どであり、地震荷重のようなランダムな載荷履歴を受けた場合に破 断に至るまでの変形能力がどのように決定づけられるかについては 十分解明されているとは言い難い。例えば軸方向に繰り返し載荷を
受ける鋼材の場合、定振幅載荷を受ける場合の疲労寿命の実験式で ある Manson-Coffin 式 ${ }^{6,7)}$ と Miner 則 ${ }^{8}$ を組み合わせて破断に至るま での変形性能を評価することが一般的に行われているが 9外、、地震 荷重下において破断に至る鋼部材の破断箇所が受ける歪履歴のよう

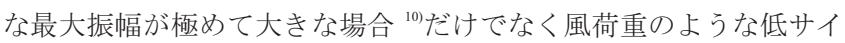
クル疲労の領域においても ${ }^{11}$ 対応が悪いことが報告されている。

Manson-Coffin 式と Miner 則の組み合わせ以外の方法として、繰 り返し載荷を受ける鋼部材や鋼材の履歴曲線を骨格曲線とバウシン ガー部に分解したうえで、骨格曲線に着目して塑性変形能力の評価 を行う方法がある 1)。この手法は、繰り返し載荷を受ける鋼材の応 力度-歪度関係に関する経験則 ${ }^{12}$ に基づくものであり、最近では鋼

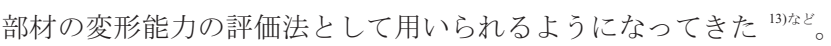
筆者らは既報 ${ }^{14}$ において、一定軸力と繰り返し曲げを受ける鋼部材 を対象に、バウシンガー効果を考慮した応力度-歪度関係のモデル ${ }^{15}$ を適用した解析を行い、部材の荷重一変形関係が骨格曲線上にある とき、最大耐力を決定づける箇所においても応力度-歪度関係は骨 格曲線上にあることを示したが、任意の載荷履歴を受ける鋼材が破 断に至る条件については検討できておらず、鋼材の変形性能と鋼部 材の塑性変形能力を対応づけるには至っていない。破断に着目した 場合、地震荷重下で破断に至る箇所が受ける歪履歴と鋼素材の塑性

\footnotetext{
*1 東京工業大学建築物理研究センター 准教授・博士 (工学) Assoc. Prof., Structural Engineering Research Center, Tokyo Institute of Technology,

*2 東京工業大学大学院 大学院生 $\cdot$ 修士 (工学)

*3 東京工業大学建築物理研究センター 助教・博士 (工学)

*4 元 東京工業大学大学院 大学院生 · 修士 (工学) (中部電力) Dr. Eng.

Graduate Student, Tokyo Institute of Technology, M. Eng.

Assist. Prof., Structural Engineering Research Center, Tokyo Institute of Technology, Dr. Eng.

Former Graduate Student, Tokyo Institute of Technology, M. Eng.

CHUBU Electric Power
} 
変形能力の関係を把握することは重要な課題であり、様々な載荷履 歴のもとでの素材レベルでの実験データーは、ランダムな外乱であ る地震荷重下での部材の塑性変形能力を評価する上で、重要な基礎 データーとなる。

本研究では、一般構造用鋼材 SS400 と建築構造用鋼材 SN400 を 対象に、小型要素試験体を用いて載荷履歴をパラメーターとした軸 方向繰り返し載荷実験を行った。実験結果について、履歴曲線から 抽出した骨格曲線・バウシンガー部それぞれの吸収エネルギーに着 目して整理・検討し、繰り返し載荷を受ける鋼材が破断に至るまで の変形性能を評価する。

\section{2. 要素試験体の軸方向繰り返し載荷実験}

\section{1 試験体}

本研究では板厚 $12 \mathrm{~mm}$ の鋼板から圧延方向と載荷方向が一致す るように切り出した図 1 に示寸形状を有する要素試験体を用いて、 軸方向繰り返し載荷試験を行った。試験体一覧をパラメーターと併 せて表 1 に示す。本実験では鋼材(ロット)と 2.3 節で説明する載荷 履歴がパラメーターとなっており、SS400 材について 4 ロット 28 体、SN400 材について 1 ロット 18 体の計 46 体の試験体を用いた。 JIS-1A 号試験片による使用鋼材の引張試験結果を図 2 に示す。試 験区間は幅 $40 \mathrm{~mm}$ で長さ $100 \mathrm{~mm}(\mathrm{FF} 01,02,03$ のみ長さ $80 \mathrm{~mm})$ であ り、試験区間両端の接合部には試験区間の軸方向長さの変化を計測 するため、変位計接続用のねじ棒が点付け溶接されている。また、 試験区間端部は応力集中による早期破断を回避するためコーナー R をとっており、鋼材(1)〜 (4)(SS400)を用いた試験体では $\mathrm{R}=10 \mathrm{~mm}$ 、 鋼材(5)(SN400)を用いた試験体では $\mathrm{R}=20 \mathrm{~mm}$ とした。
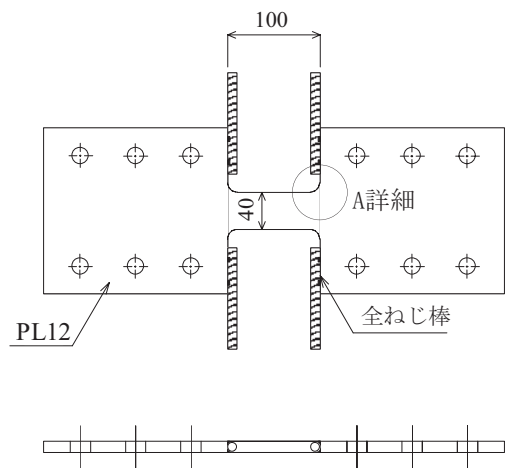

図1 試験体形状

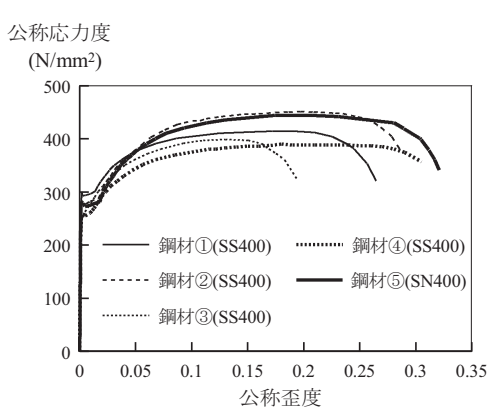

図2 使用鋼材の公称応力度-公称歪度関係

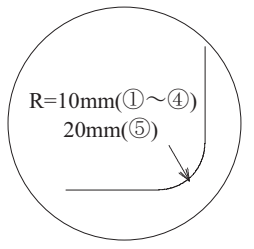

A詳細

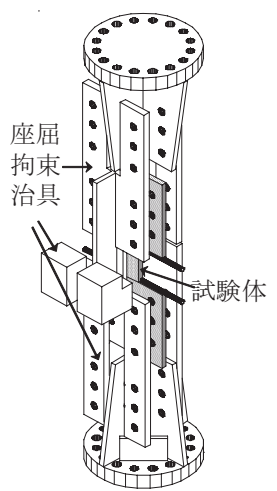

図3 セットアップ

\section{2 実験方法}

セットアップを図 3 に示す。載荷には機械式 $500 \mathrm{kN}$ 試験機を用 い、圧縮力下での試験区間における座屈を抑えるため、試験体周囲 には図 3 に示寸面外変形拘束治具を設置した。この治具は、試験区 間において強軸、弱軸ともに面外変形を拘束するものであり、試験 体との間には摩擦力の発生を防ぐために一定の隙間を設け、隙間に はテフロンシートを挟んだ。圧縮力下における試験区間での体積増 加についても、この隙間とテフロンシートの変形で対応させた。試 験体に作用する軸力は試験機クロスヘッドに内蔵されたロードセル で計測し、試験区間の変形については、両端の変位をバネ式変位計 で計測した。

\section{3 載荷履歴}

本実験の主たるパラメーターは、鋼材が受ける軸方向の載荷履歴 である。パラメーターの詳細を表 1 に示す。設定した載荷履歴は大 きく分けて、(1)一定の振幅で破断に至るまで繰り返し載荷を行う「定 振幅載荷」、(2)一定の振幅で複数回数繰り返し載荷を行った後引張 載荷を行う「定振幅 $\rightarrow$ 引張載荷」、(3)同一の振幅で複数回繰り返し 載荷を行う漸増振幅載荷を行った後引張載荷を行う「漸増振幅 $\rightarrow 引$ 張載荷」、(4)一定振幅で複数回数繰り返し載荷を行った後、中央值 を引張側にオフセットさせ再び同じ振幅で複数回数繰り返し載荷を 行うことを繰り返していく「オフセット載荷」、(5)ランダムな履歴 で繰り返し載荷を行った後引張載荷を行う「ランダム $\rightarrow 引$ 張載荷」 そして(6)「単調引張載荷」の 6 つの基本パターンを設定した。基本 パターンの概要を図 4 に示す。図 4 中に示すように、本研究では振 幅を全振幅 $\varepsilon_{t}$ で表し、振幅の中央值 $\varepsilon_{0}$ 、繰り返し数 $N$ と併せて表 1 中 に示している。

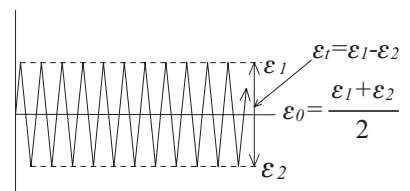

(1) 定振幅載荷

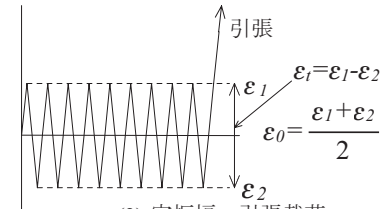

（2）定振幅 $\rightarrow$ 引張載荷

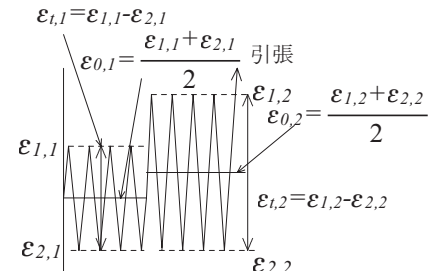

(3) 漸増振幅 $\rightarrow$ 引張載荷

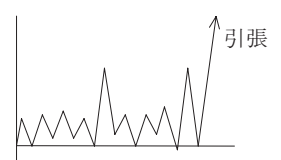

(5) ランダム $\rightarrow$ 引張載荷

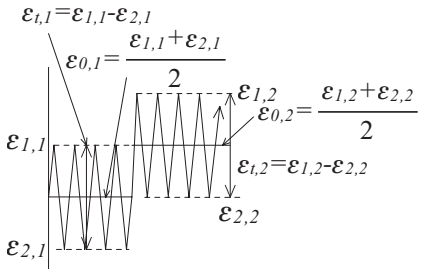

(4) オフセット載荷
図4 基本的な載荷パターン 


\section{4 実験結果}

実験結果の一覧を表 1 に示す。本実験では、試験体に作用した軸 力を試験区間の原断面積で除して公称応力度 $n \sigma$ を、試験区間軸方向 の長さの変化を試験区間元長さで除して公称歪度 $n \varepsilon を$ 得た。符号は 引張側を正とした。これを、体積一定の仮定のもとで、式(1),(2)に より真応力度-対数歪関係 $(t \sigma-t \varepsilon$ 関係 $)$ に置換した。各載荷パターンで の代表的な実験結果を図 5 に示寸。

$$
\begin{aligned}
& { }_{t} \sigma=\left(1+{ }_{n} \varepsilon\right) \cdot{ }_{n} \sigma \\
& { }_{i} \varepsilon=\ln \left(1+{ }_{n} \varepsilon\right)
\end{aligned}
$$

一般的な鋼材の変形性能に関する研究では、亀裂発生点や断面が 完全に離れる状態までの変形性能を論じることが多いが、本研究で は真応力度-対数歪関係において勾配が負に転じた時点を以て最終 状態に達したと判断した。これは鋼材の変形性能と部材の変形性能 の対応をマクロに捉えるには、一様伸びレベルでの変形性能を把握

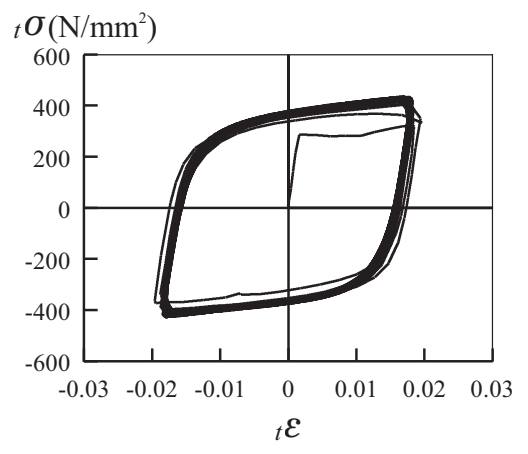

(1)定振幅載荷(S23)

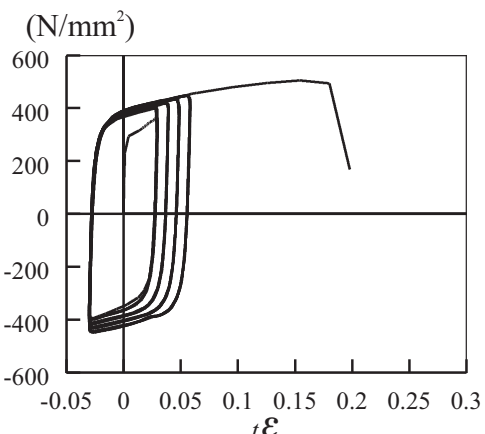

(4)漸増振幅 $\rightarrow$ 引張載荷(B09)

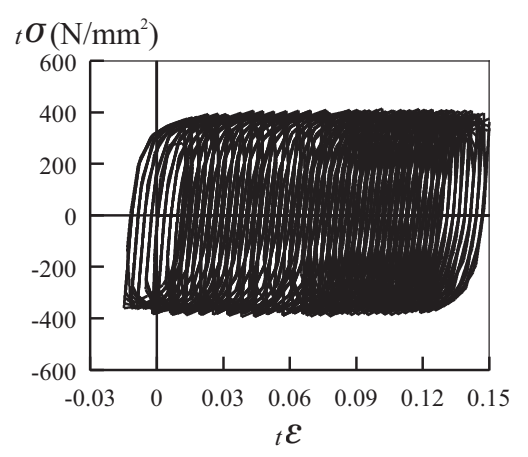

(7)オフセット載荷(S34)

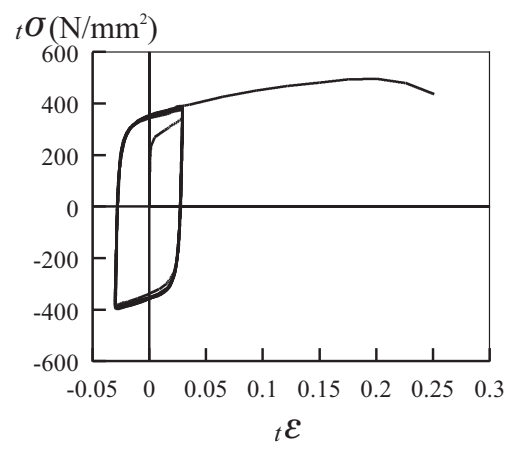

(2) 定振幅 $\rightarrow$ 引張載荷(B01)

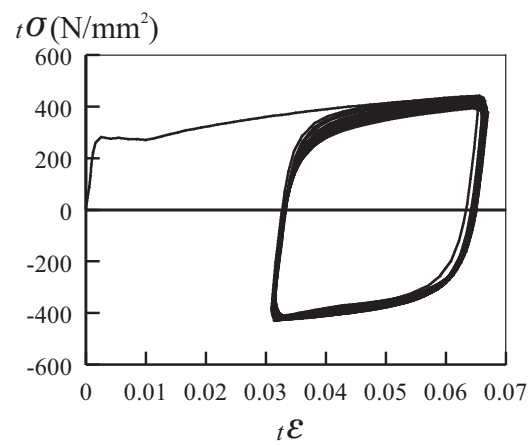

(5)オフセット載荷(S28)

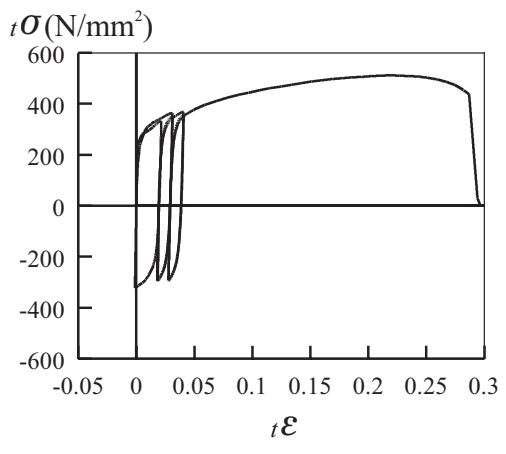

(8)ランダム $\rightarrow$ 引張載荷(B15)

図5 真応力度-対数歪関係の例

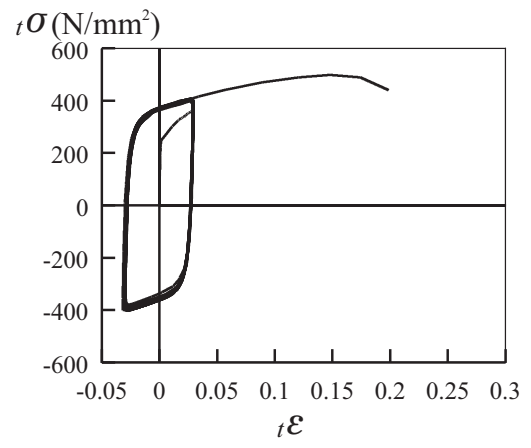

(3)定振幅 $\rightarrow$ 引張載荷(B08)

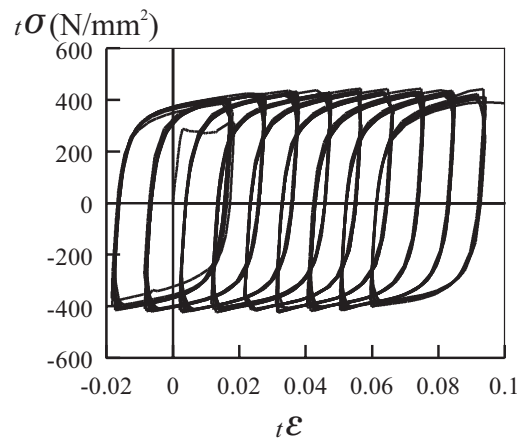

(6)オフセット載荷(S30)

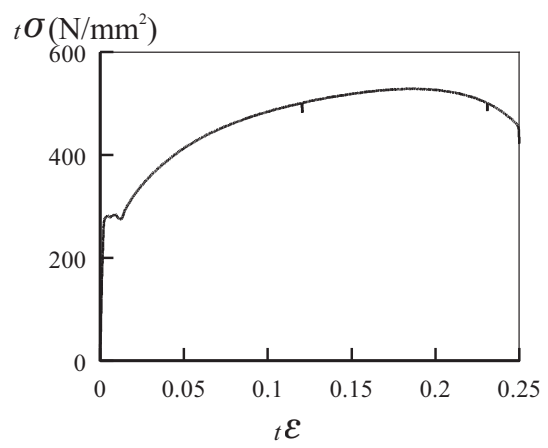

(9)単調引張載荷(S20) 
表1 試験体ならびに実験結果の一覧

\begin{tabular}{|c|c|c|c|c|c|c|c|c|c|c|c|c|c|}
\hline 試験体 & 鋼種 & 鋼材 & 降伏点 & 載荷パターン & 載荷履歴 ※1 & $\bar{\eta} s^{+}$ & $\bar{\eta}_{s}$ & $\bar{\eta}_{B}^{+}$ & $\bar{n}_{B^{-}}$ & $\eta s^{+}$ & $\eta s^{-}$ & $\eta_{B^{+}}$ & $\eta_{B^{-}}$ \\
\hline B01 & \multirow{11}{*}{ SS400 } & \multirow{11}{*}{ (1) } & \multirow{11}{*}{291.4} & 定振幅 $\rightarrow$ 引張載荷 & $6 \%(0 \%) \times 10 \rightarrow$ 引張 & 236.9 & 58.2 & 400.6 & 384.8 & 163.3 & 49.1 & 351.6 & 328.0 \\
\hline B05 & & & & 漸増振幅 $\rightarrow$ 引張載荷 & $6 \%(0 \%) \times 5 \rightarrow 7 \%(0.5 \%) \times 5 \rightarrow 8 \%(1 \%) \times 5 \rightarrow$ 引張 & 211.7 & 76.3 & 774.0 & 706.3 & 141.3 & 61.6 & 624.1 & 582.4 \\
\hline B06 & & & & 定振幅載荷 & $6 \%(0 \%) \times 57.5$ & 64.0 & 64.6 & 2517.0 & 2464.8 & 51.4 & 53.2 & 2096.9 & 2057.4 \\
\hline B07 & & & & 定振幅 $\rightarrow$ 引張載荷 & $6 \%(0 \%) \times 50 \rightarrow$ 引張 & 161.5 & 65.4 & 2155.4 & 2190.9 & 114.2 & 53.5 & 1848.3 & 1805.6 \\
\hline B08 & & & & 定振幅 $\rightarrow$ 引張載荷 & $6 \%(0 \%) \times 40 \rightarrow$ 引張 & 192.1 & 57.1 & 1769.7 & 1686.3 & 129.9 & 48.6 & 1469.4 & 1436.6 \\
\hline B09 & & & & 漸増振幅 $\rightarrow$ 引張載荷 & $6 \%(0 \%) \times 5 \rightarrow 7 \%(0.5 \%) \times 5 \rightarrow 8 \%(1 \%) \times 5 \rightarrow 9 \%(1.5 \%) \times 5 \rightarrow$ 引張 & 219.6 & 103.9 & 1162.6 & 1084.9 & 146.0 & 78.5 & 903.6 & 853.8 \\
\hline B10 & & & & 漸増振幅 $\rightarrow$ 引張載荷 & $\begin{array}{l}6 \%(0 \%) \times 5 \rightarrow 7 \%(0.5 \%) \times 5 \rightarrow 8 \%(1 \%) \times 5 \rightarrow 9 \%(1.5 \%) \times 5 \rightarrow 10 \%(2 \%) \times 5 \rightarrow \\
\text { 引張 }\end{array}$ & 108.4 & 128.5 & 1550.2 & 1465.7 & 82.7 & 80.4 & 1220.3 & 1148.0 \\
\hline B15 & & & & ランダム $\rightarrow$ 引張載荷 & ランダム履歴 ${ }^{* 2} \times 1 \rightarrow$ 引張 & 221.1 & 13.1 & 50.4 & 21.4 & 145.1 & 13.6 & 47.5 & 26.4 \\
\hline B18 & & & & ランダム $\rightarrow$ 引張載荷 & ランダム履歴米 ×2 $\rightarrow$ 引張 & 220.5 & 16.9 & 117.1 & 48.8 & 139.6 & 16.7 & 101.1 & 59.7 \\
\hline $\mathrm{B} 20$ & & & & 定振幅載荷 & $4.2 \%(0 \%) \times 143.5$ & 52.4 & 50.3 & 4253.3 & 4374.2 & 43.1 & 42.0 & 3762.7 & 3758.9 \\
\hline B49 & & & & 単調引張載荷 & & 220.4 & & & & 143.8 & - & - & - \\
\hline D1 & \multirow{7}{*}{ SS 400} & \multirow{7}{*}{ (2) } & \multirow{7}{*}{304.7} & 単調引張載荷 & & 199.9 & & & & 123.4 & - & - & - \\
\hline D20 & & & & 定振幅 $\rightarrow 引$ 張載荷 & $2.5 \%(1.25 \%) \times 1 \rightarrow 引$ 張 & 193.5 & 15.8 & 6.8 & 0.0 & 128.5 & 16.0 & 12.2 & 0.0 \\
\hline D22 & & & & 定振幅 $\rightarrow$ 引張載荷 & $5 \%(2.5 \%) \times 1 \rightarrow$ 引張 & 212.6 & 38.5 & 23.2 & 23.2 & 136.1 & 32.6 & 25.0 & 0.0 \\
\hline D29 & & & & 定振幅 $\rightarrow$ 引張載荷 & $7.5 \%(3.75 \%) \times 1 \rightarrow$ 引張 & 187.4 & 61.7 & 43.0 & 0.0 & 127.1 & 46.9 & 35.9 & 0.0 \\
\hline D34 & & & & 定振幅 $\rightarrow$ 引張載荷 & $5 \%(0 \%) \times 3 \rightarrow$ 引張 & 197.4 & 52.5 & 81.5 & 66.7 & 132.2 & 43.0 & 70.1 & 54.5 \\
\hline D58 & & & & 定振幅 $\rightarrow$ 引張載荷 & $10 \%(0 \%) \times 3 \rightarrow$ 引張 & 140.1 & 104.6 & 191.3 & 145.4 & 96.8 & 76.7 & 133.6 & 103.8 \\
\hline D62 & & & & 定振幅 $\rightarrow$ 引張載荷 & $2.4 \%(0 \%) \times 3 \rightarrow$ 引張 & 195.8 & 18.4 & 18.0 & 15.2 & 130.9 & 17.5 & 17.2 & 14.9 \\
\hline E01 & \multirow{3}{*}{ SS 400} & \multirow{3}{*}{ (3) } & \multirow{3}{*}{245.2} & 単調引張載荷 & & 265.7 & & & & 143.0 & - & - & - \\
\hline E02 & & & & 定振幅 $\rightarrow$ 引張載荷 & $6.4 \%(0 \%) \times 10 \rightarrow$ 引張 & 220.7 & 75.3 & 627.8 & 604.2 & 126.8 & 50.5 & 435.1 & 402.3 \\
\hline E05 & & & & 漸増振幅 $\rightarrow$ 引張載荷 & $6.4 \%(0 \%) \times 5 \rightarrow 7.4 \%(0.5 \%) \times 5 \rightarrow 8.4 \%(1 \%) \times 5 \rightarrow$ 引張 & 246.6 & 121.1 & 1221.7 & 1204.1 & 144.9 & 75.1 & 801.4 & 757.7 \\
\hline F01 & \multirow{7}{*}{ SS400 } & \multirow{7}{*}{ (4) } & \multirow{7}{*}{242.6} & 単調引張載荷 & & 324.7 & & & & 183.7 & - & - & - \\
\hline F02 & & & & 定振幅載荷 & $4.2 \%(0 \%) \times 180.5$ & 68.1 & 68.7 & 7280.5 & 5619.5 & 50.4 & 49.6 & 5616.1 & 5615.1 \\
\hline F03 & & & & 定振幅 $\rightarrow$ 引張載荷 & $6.2 \%(0 \%) \times 41 \rightarrow$ 引張 & 206.9 & 80.1 & 2726.7 & 2837.3 & 128.8 & 55.5 & 1865.6 & 1904.6 \\
\hline F04 & & & & 定振幅載荷 & $4.2 \%(0 \%) \times 123.5$ & 71.9 & 54.6 & 5176.8 & 5330.9 & 51.7 & 40.0 & 3875.7 & 3873.8 \\
\hline FF01 & & & & 単調引張載荷 & & 322.1 & & & & 183.7 & -1 & - & - \\
\hline FF02 & & & & オフセット載荷 & $3.9 \%(9.55 \%) \times 141.5$ & 126.0 & 43.3 & 5551.8 & 5636.6 & 83.1 & 28.8 & 4136.0 & 4095.9 \\
\hline FF03 & & & & オフセット載荷 & $5.7 \%(9.65 \%) \times 41 \rightarrow$ 引張 & 146.9 & 73.6 & 2793.6 & 2623.7 & 92.9 & 45.5 & 1861.2 & 1749.5 \\
\hline S20 & \multirow{18}{*}{ SN400 } & \multirow{18}{*}{ (5) } & & \multirow{13}{*}{\begin{tabular}{|l} 
単調引張載荷 \\
定振幅載荷 \\
定振幅載荷 \\
定振幅載荷 \\
定振幅載荷 \\
オフセット載荷 \\
オフセット載荷 \\
オフセット載荷 \\
オフセット載荷 \\
\end{tabular}} & & 196.9 & & & & 120.1 & - & - & - \\
\hline S21 & & & & & $5.6 \%(0 \%) \times 48.5$ & 97.6 & 97.8 & 2421.5 & 2426.4 & 67.7 & 63.3 & 1703.8 & 1698.7 \\
\hline S23 & & & & & $3.6 \%(0 \%) \times 126.5$ & 52.1 & 56.6 & 3690.0 & 3675.7 & 39.0 & 43.5 & 2851.9 & 2852.9 \\
\hline S24 & & & & & $1.6 \%(0 \%) \times 532.5$ & 25.8 & 25.6 & 5032.6 & 5078.8 & 20.4 & 19.2 & 4479.5 & 4508.1 \\
\hline$\underline{\mathrm{S} 25}$ & & & & & $2.6 \%(0 \%) \times 234.5$ & 37.9 & 36.6 & 4440.8 & 4462.3 & 30.3 & 30.0 & 3765.9 & 3765.9 \\
\hline S26 & & & & & $1.8 \%(1.9 \%) \times 449.5$ & 52.7 & 51.0 & 3133.4 & 3146.0 & 23.0 & 19.0 & 4603.1 & 4625.7 \\
\hline S27 & & & & & $3.8 \%(1 \%) \times 109.5$ & 52.7 & 51.0 & 3133.4 & 3146.0 & 40.7 & 39.4 & 2498.6 & 2487.2 \\
\hline S28 & & & & & $3.5 \%(4.8 \%) \times 97.5$ & 63.6 & 38.4 & 2835.8 & 2833.0 & 47.3 & 28.2 & 2225.0 & 2198.4 \\
\hline S29 & & & & & $3.6 \%(-1.1 \%) \times 106.5$ & 49.3 & 49.8 & 3035.2 & 3016.9 & 37.5 & 39.4 & 2413.6 & 2401.3 \\
\hline S30 & & & & & $\begin{array}{l}3.6 \%(0 \%) \times 10 \rightarrow 3.6 \%(1 \%) \times 10 \rightarrow 3.6 \%(2 \%) \times 10 \rightarrow 3.6 \%(3 \%) \times 10 \rightarrow 3.5 \%( \\
4 \%) \times 10 \rightarrow 3.5 \%(5 \%) \times 10 \rightarrow 3.5 \%(6 \%) \times 10 \rightarrow 3.5 \%(7 \%) \times 10 \rightarrow 3.5 \%(8 \%) \times 6 \\
.5\end{array}$ & 70.0 & 51.7 & 2607.2 & 2471.1 & 51.3 & 40.0 & 1995.3 & 1935.5 \\
\hline$\underline{\mathrm{S} 31}$ & & & & & $3.5 \%(7.7 \%) \times 92.5$ & 97.4 & 31.3 & 2593.9 & 2542.6 & 67.4 & 22.9 & 2071.6 & 2056.3 \\
\hline S32 & & & & & $\begin{array}{l}3.7 \%(0 \%) \times 6 \rightarrow 3.6 \%(1 \%) \times 4 \rightarrow 3.6 \%(2 \%) \times 5 \rightarrow 3.6 \%(3 \%) \times 5 \rightarrow 3.5 \%(4 \%) \times \\
4 \rightarrow 3.5 \%(5 \%) \times 5 \rightarrow 3.5 \%(6 \%) \times 6 \rightarrow 3.5 \%(7 \%) \times 4 \rightarrow 3.5 \%(8 \%) \times 5 \rightarrow 3.4 \%(9) \\
\%) \times 5 \rightarrow 3.4 \%(10 \%) \times 6 \rightarrow 3.4 \%(11 \%) \times 4 \rightarrow 4.1 \%(11.5 \%) \times 5 \rightarrow 4.7 \%(12 \%) \times \\
6 \rightarrow 4 \%(14 \%) \times 5 \rightarrow 4 \%(15 \%) \times 4 \rightarrow 4 \%(16 \%) \times 4.5\end{array}$ & 81.4 & 61.9 & 2646.8 & 2498.4 & 58.6 & 46.7 & 2056.0 & 1966.4 \\
\hline S33 & & & & & $\begin{array}{l}3 \%(0 \%) \times 5 \rightarrow 3 \%(0.3 \%) \times 5 \rightarrow 3 \%(0.6 \%) \times 5 \rightarrow 3 \%(0.9 \%) \times 5 \rightarrow 3 \%(1.2 \%) \times 4 \\
\rightarrow 3 \%(1.5 \%) \times 5 \rightarrow 2.9 \%(1.8 \%) \times 5 \rightarrow 2.9 \%(2.1 \%) \times 5 \rightarrow 2.9 \%(2.4 \%) \times 5 \rightarrow 2.9 \\
\%(2.7 \%) \times 5 \rightarrow 2.9 \%(3 \%) \times 6 \rightarrow 2.9 \%(3.3 \%) \times 6 \rightarrow 2.9 \%(3.6 \%) \times 5 \rightarrow 2.9 \%(3.9 \\
\%) \times 5 \rightarrow 2.9 \%(4.2 \%) \times 5 \rightarrow 2.9 \%(4.5 \%) \times 5 \rightarrow 2.9 \%(4.8 \%) \times 5 \rightarrow 2.8 \%(5.1 \%) \times \\
5 \rightarrow 2.8 \%(5.4 \%) \times 5 \rightarrow 2.8 \%(5.7 \%) \times 5 \rightarrow 2.8 \%(6 \%) \times 5 \rightarrow 2.8 \%(6.3 \%) \times 5 \rightarrow 2 . \\
8 \%(6.6 \%) \times 5 \rightarrow 2.8 \%(6.9 \%) \times 5 \rightarrow 2.8 \%(7.2 \%) \times 5 \rightarrow 2.8 \%(7.5 \%) \times 5 \rightarrow 2.7 \%( \\
7.8 \%) \times 5 \rightarrow 2.7 \%(8.1 \%) \times 5 \rightarrow 3 \%(8.4 \%) \times 5 \rightarrow 3 \%(8.6 \%) \times 5 \rightarrow 3 \%(8.9 \%) \times 5 \\
\rightarrow 3 \%(9.2 \%) \times 5 \rightarrow 3 \%(9.5 \%) \times 5 \rightarrow 2.8 \%(9.8 \%) \times 5 \rightarrow 2.7 \%(10 \%) \times 5 \rightarrow 2.7 \%( \\
10.2 \%) \times 5 \rightarrow 2.7 \%(10.5 \%) \times 5 \rightarrow 2.7 \%(10.8 \%) \times 5 \rightarrow 2.7 \%(11.1 \%) \times 5 \rightarrow 2.7 \% \\
(11.4 \%) \times 5 \rightarrow 2.7 \%(11.7 \%) \times 6 \rightarrow 2.7 \%(12 \%) \times 5 \rightarrow 2.7 \%(12.3 \%) \times 4 \rightarrow 2.7 \% \\
(12.6 \%) \times 6 \rightarrow 2.7 \%(12.9 \%) \times 5 \rightarrow 2.7 \%(13.2 \%) \times 3.5\end{array}$ & 40.4 & 39.0 & 4818.2 & 4776.0 & 39.2 & 29.2 & 3761.6 & 3710.8 \\
\hline S34 & & & & オフセット載荷 & $\begin{array}{l}3 \%(0 \%) \times 5 \rightarrow 3 \%(0.28 \%) \times 5 \rightarrow 3 \%(0.6 \%) \times 5 \rightarrow 3 \%(0.9 \%) \times 5 \rightarrow 3 \%(1.2 \%) \times \\
5 \rightarrow 3 \%(1.5 \%) \times 5 \rightarrow 2.9 \%(1.8 \%) \times 5 \rightarrow 2.9 \%(2.1 \%) \times 5 \rightarrow 2.9 \%(2.4 \%) \times 5 \rightarrow 2 . \\
9 \%(2.7 \%) \times 5 \rightarrow 2.9 \%(2.9 \%) \times 5 \rightarrow 2.9 \%(3.2 \%) \times 5 \rightarrow 2.9 \%(3.5 \%) \times 5 \rightarrow 2.9 \%( \\
3.8 \%) \times 5 \rightarrow 2.9 \%(4.1 \%) \times 5 \rightarrow 2.9 \%(4.4 \%) \times 5 \rightarrow 2.9 \%(4.7 \%) \times 5 \rightarrow 2.8 \%(5.0 \\
\%) \times 5 \rightarrow 2.8 \%(5.2 \%) \times 5 \rightarrow 2.8 \%(5.5 \%) \times 5 \rightarrow 2.8 \%(5.8 \%) \times 5 \rightarrow 2.8 \%(6.1 \%) \times \\
5 \rightarrow 2.8 \%(6.4 \%) \times 5 \rightarrow 2.8 \%(6.6 \%) \times 5 \rightarrow 2.8 \%(6.9 \%) \times 5 \rightarrow 2.8 \%(7.2 \%) \times 5 \rightarrow \\
2.8 \%(7.5 \%) \times 5 \rightarrow 2.8 \%(7.8 \%) \times 5 \rightarrow 2.8 \%(8.0 \%) \times 5 \rightarrow 2.8 \%(8.3 \%) \times 5 \rightarrow 2.7 \\
\%(8.6 \%) \times 5 \rightarrow 2.7 \%(8.9 \%) \times 5 \rightarrow 2.7 \%(9.2 \%) \times 5 \rightarrow 2.7 \%(9.4 \%) \times 5 \rightarrow 2.7 \%(9 \\
.7 \%) \times 5 \rightarrow 2.7 \%(10.0 \%) \times 5 \rightarrow 2.7 \%(10.3 \%) \times 5 \rightarrow 2.7 \%(10.5 \%) \times 5 \rightarrow 2.7 \%(1 \\
0.8 \%) \times 5 \rightarrow 2.7 \%(11.0 \%) \times 5 \rightarrow 2.7 \%(11.3 \%) \times 5 \rightarrow 2.7 \%(11.6 \%) \times 5 \rightarrow 2.7 \%( \\
11.8 \%) \times 5 \rightarrow 2.7 \%(12.1 \%) \times 5 \rightarrow 2.7 \%(12.4 \%) \times 5 \rightarrow 2.6 \%(12.6 \%) \times 5 \rightarrow 2.6 \\
\%(12.9 \%) \times 5 \rightarrow 2.6 \%(13.1 \%) \times 5 \rightarrow 2.6 \%(13.4 \%) \times 5 \rightarrow 2.6 \%(13.7 \%) \times 4.5\end{array}$ & 46.7 & 32.7 & 4756.3 & 4364.9 & 36.9 & 27.4 & 3867.6 & 3772.6 \\
\hline$\underline{\mathrm{S} 35}$ & & & & オフセット載荷 & $2.6 \%(13.5 \%) \times 151.5$ & 163.6 & 18.7 & 2650.6 & 2621.3 & 104.0 & 13.7 & 2191.4 & 2232.3 \\
\hline S36 & & & & 定振幅載荷 & $2.6 \%(0 \%) \times 251.5$ & 40.4 & 39.0 & 4818.2 & 4776.0 & 32.2 & 31.8 & 3998.2 & 3986.3 \\
\hline S37 & & & & オフセット載荷 & $2.3 \%(15.8 \%) \times 143.5$ & 189.6 & 17.7 & 2424.6 & 2336.4 & 116.6 & 12.8 & 1995.0 & 1993.1 \\
\hline S39 & & & & オフセット載荷 & $\begin{array}{l}3.6 \%(0 \%) \times 5 \rightarrow 3.6 \%(0.5 \%) \times 5 \rightarrow 3.6 \%(1 \%) \times 5 \rightarrow 3.6 \%(1.5 \%) \times 5 \rightarrow 3.5 \%(1 . \\
9 \%) \times 5 \rightarrow 3.5 \%(2.4 \%) \times 5 \rightarrow 3.6 \%(2.9 \%) \times 5 \rightarrow 3.5 \%(3.4 \%) \times 5 \rightarrow 3.5 \%(3.9 \%) \\
\times 5 \rightarrow 3.5 \%(4.4 \%) \times 5 \rightarrow 3.5 \%(4.8 \%) \times 5 \rightarrow 3.4 \%(5.3 \%) \times 5 \rightarrow 3.4 \%(5.8 \%) \times 5 \\
\rightarrow 3.4 \%(6.3 \%) \times 5 \rightarrow 3.4 \%(6.7 \%) \times 5 \rightarrow 3.4 \%(7.2 \%) \times 5 \rightarrow 3.4 \%(7.7 \%) \times 5 \rightarrow 3 . \\
3 \%(8.1 \%) \times 5 \rightarrow 3.3 \%(8.6 \%) \times 5 \rightarrow 3.3 \%(9 \%) \times 5 \rightarrow 3.3 \%(9.5 \%) \times 5 \rightarrow 3.3 \%(1 \\
0 \%) \times 5 \rightarrow 3.3 \%(10.4 \%) \times 3.5\end{array}$ & 63.9 & 48.8 & 3191.2 & 3025.6 & 49.3 & 39.5 & 2534.1 & 2483.7 \\
\hline
\end{tabular}

$※ 1$ 表記は全振幅 $\varepsilon_{t}$ (振幅の中央值 $\left.\varepsilon_{0}\right) \times$ 繰り返し数 $N, \quad ※ 2$ 弾塑性応答解析結果(応答変位の履歷)を基に作成 


\section{3. 骨格曲線に着目した鋼材要素の塑性変形能力評価}

鋼材が延性的に破断するまでの塑性変形能力は、履歴に占める骨 格曲線とバウシンガー部の割合との間に強い関係があることが、載 荷履歴をパラメーターとした丸棒の曲げ実験によって明らかにされ ている ${ }^{(6)}$ 。軸方向に繰り返し荷重を受ける鋼材要素の塑性変形能力 が同様に評価できるかを検討する。検討にあたり、まず破断するま でに吸収した歪エネルギーの総量を単位塑性歪エネルギーで除した 等価累積塑性歪倍率 $\bar{\eta}_{T}$ で表す。 $\bar{\eta}_{T}$ は表 1 中に示した正側と負側そ れぞれの骨格曲線およびバウシンガー部の等価累積塑性歪倍率 $\bar{\eta} s^{+}$、 $\bar{\eta}_{S} 、 \bar{\eta}_{B^{+}} 、 \bar{\eta}_{B^{-}}$の総和である。さらに、異なる鋼材のエネルギー吸 収能力を統一的に評価するため、単調引張載荷を行った試験体の等 価累積塑性歪倍率 $\bar{\eta} s^{+}$を $\bar{\eta}_{0}$ とし、これで基準化したうえで検討を行 う。

破断するまでに鋼材が吸収できるエネルギー量と、引張側骨格曲 線での吸収エネルギーの関係を、 $\bar{\eta}_{T} / \bar{\eta}_{0}$ と $\bar{\eta}_{S^{+}} / \bar{\eta}_{0}$ の関係としてプロ ットし、図 7 に示す。載荷履歴によらず両者の関係は図中に破線で 示した式(3)で代表できる。

$$
\begin{aligned}
& \bar{\eta}_{T} / \bar{\eta}_{0}=50\left(1-\bar{\eta}_{S^{+}} / \bar{\eta}_{0}\right)+1 \\
& \left(0.13 \leqq \bar{\eta}_{S^{+}} / \bar{\eta}_{0} \leqq 1.0\right)
\end{aligned}
$$

式(3)は歪エネルギーによる整理であり、鋼材のエネルギー吸収 能力の直接的な表現であるが、部材の限界変形などを検討する上で は歪で表した方が扱いやすい。そこで、破断するまでの累積塑性歪 倍率である、正側と負側それぞれの骨格曲線およびバウシンガー部 の累積塑性歪倍率 $\eta_{S^{+}} 、 \eta_{S^{-}} 、 \eta_{B^{+}}{ }^{+} 、 \eta_{B}{ }^{-}$の総和 $\eta_{T}=\eta s^{+}+\eta s^{+} \eta_{B^{+}}+\eta_{B}{ }^{-}$と、 引張側骨格曲線での累積塑性歪倍率 $\eta s^{+}$の関係を、単調引張載荷を 行った試験体の累積塑性歪倍率 $\eta_{s^{+}}$を $\eta_{0}$ とし、 $\eta_{T} / \eta_{0}$ と $\eta_{s^{+}} / \eta_{0}$ の関係と してプロットし、図 8 に示す。 $\eta_{T} / \eta_{0}$ と $\eta_{s^{+}} / \eta_{0}$ で整理した場合につい ても、載荷履歴によらずほぼ図中に破線で示した式(4)で代表でき る関係が見られる。

$$
\begin{aligned}
& \eta_{T} / \eta_{0}=70\left(1-\eta_{s^{+}} / \eta_{0}\right)+1 \\
& \left(0.17 \leqq \eta s^{+} / \eta_{0} \leqq 1.0\right)
\end{aligned}
$$

\section{4. 鋼材要素の塑性変形能力評価法の検討}

\section{1 Manson-Coffin式による定歪振幅下での繰り返し寿命の評価}

定振幅下における鋼材の繰り返し寿命については、振幅と破断に 至るまでの繰り返し回数の関係で評価することが一般に行われてい る。振幅については、疲労の領域である線形範囲のみを扱う場合に は応力振幅が用いられるが、比較的振幅が大きい非線形領域まで統 一的に扱う場合には歪振幅が用いられる 91. は、S(振幅)-N(繰り返し回数)関係を低サイクル疲労の領域に拡張し たものであり、構造用鋼材の低サイクル疲労寿命の評価法として一 般的に用いられているだけでなく、次節で扱う Miner 則と組み合わ せることで変動振幅下における損傷評価の基礎式として用いられて いる。本研究で行った定歪振幅の実験結果について、Manson- Coffin 式(5)を得た。

$$
\Delta \varepsilon_{p}=0.6 \cdot N_{f}^{-0.57}
$$

ここで、 $\Delta \varepsilon_{p}$ は塑性歪振幅(歪で表した全振幅 $\varepsilon_{t}$ から $2 \sigma_{y} / E$ を 引いた值)、N $N_{f}$ 破断までの繰り返し数である。

図 9 に式(5)を実験結果のプロットと併せて示す。

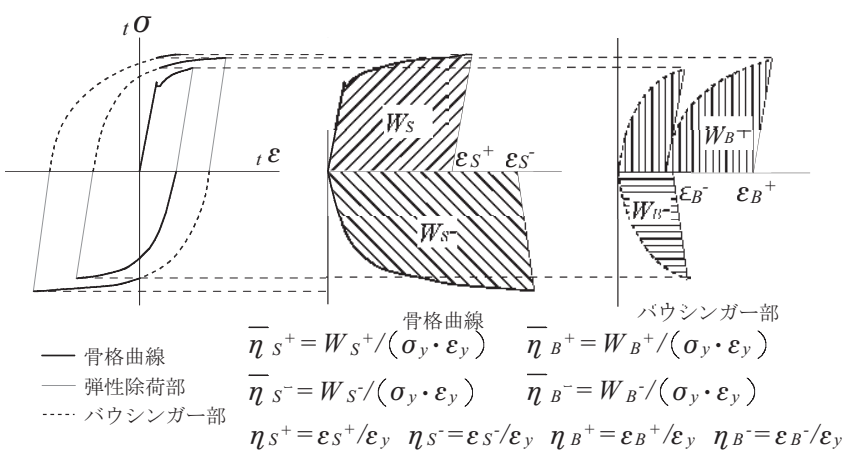

図6 履歴の分解

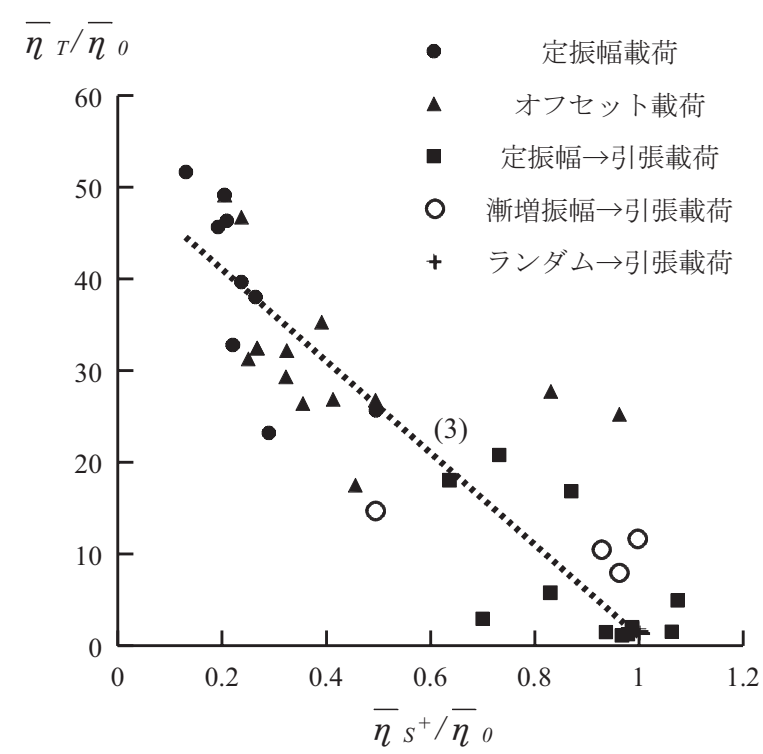

図7 $\bar{\eta}_{T} / \bar{\eta} 0-\bar{\eta} s^{+} / \bar{\eta}$ 関係 (歪エネルギーによる整理)

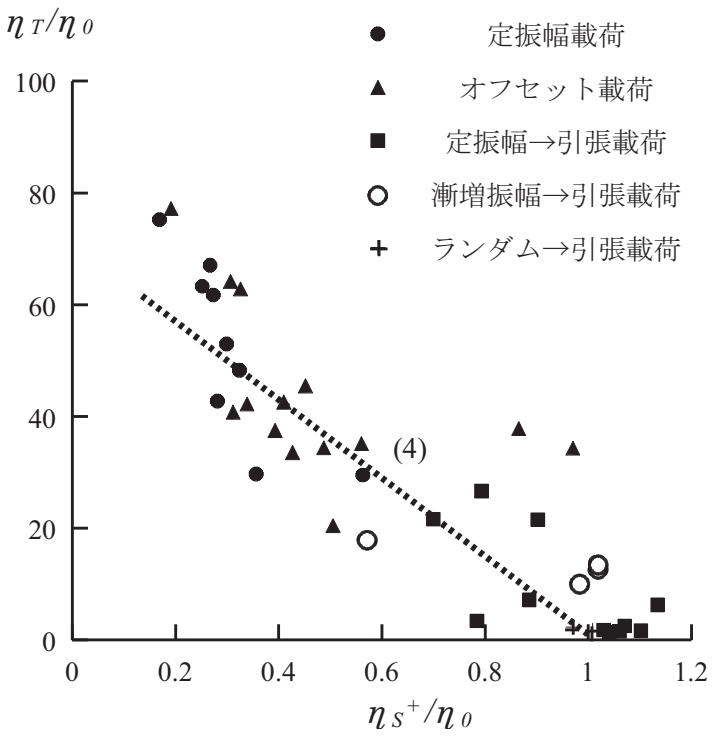

図8 $\eta_{T} / \eta_{0}-\eta^{+} / \eta_{0}$ 関係 (歪による整理) 


\section{2 Miner則による累積損傷の評価}

定振幅載荷による疲労寿命に基づき変振幅載荷下で受ける損傷を 評価する方法として、一般に Miner 則 ${ }^{8}{ }^{8}$ 用いられている。 Miner 則では、変振幅載荷を受ける中で、ある振幅での繰り返し数が $n_{i}$ 、 その振幅で定振幅載荷を行った場合に破断に至るまでの繰り返し数 が $N_{i}$ であるとき、累積損傷度

$$
D=\sum\left(n_{i} / N_{i}\right)
$$

が 1 になると破断に至るとして累積損傷を評価する。定振幅下での 破断に至るまでの繰り返し数 $N_{i}$ を式(5)で評価し、各試験体が破断し た時点での累積損傷を図 10 に示寸。図中破線で囲った試験体では、 累積損傷をかなり低く評価しているが、これらの試験体はわずかな 繰り返し載荷の後引張載荷を行ったものであり、繰り返しによる累 積歪が非常に小さいことが特徴である。また、定振幅載荷の実験結 果でも誤差の大きなものがある。なお、半サイクルごとの振幅の評 価は Rain Flow 法 ${ }^{17} に よ り$ 行ったが、より簡便なレンジ法 9)で評価 した場合においても同様の結果であった。

引張載荷に移行する前の繰り返し載荷による累積歪が小さい場合 に累積損傷を過小評価するのは、累積損傷の評価の基となる定振幅 下での破断に至るまでの繰り返し数 $N_{i}$ が、 $N_{i}$ が非常に小さくなる領 域で予測できていないことによる。単調引張載荷は、Rain Flow 法 によれば一様伸びを全振幅とする半サイクル $\left(N_{f}=0.5\right)$ の載荷と評価 できる。本実験での単調引張載荷の結果を Manson-Coffin 式(5)なら びに定歪振幅の実験結果と比較し図 11 に示す。単調引張載荷での 一様伸びは式(5)では $N_{f}=4 \sim 8$ 程度に相当し、単調引張載荷に近い領 域までは予測できていない。これは、本研究において対数歪におけ る破断伸びで整理していないことも原因であると考えられるが、部 材の変形能力との対応をマクロに捉えるには一様伸び相当の変形能 力で整理することは有効である。一様伸び相当での整理では Manson-Coffin 式では繰り返し数 $N_{i}$ が非常に小さくなる領域で適用 できないことを、ここでの考察とする。なお、歪振幅が非常に大き な領域で Manson-Coffin 式と Miner 側による予測精度が悪くなるこ とについては、極低サイクル疲労寿命に関する既往の研究でも指摘

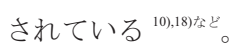

$\Delta \varepsilon_{p}$

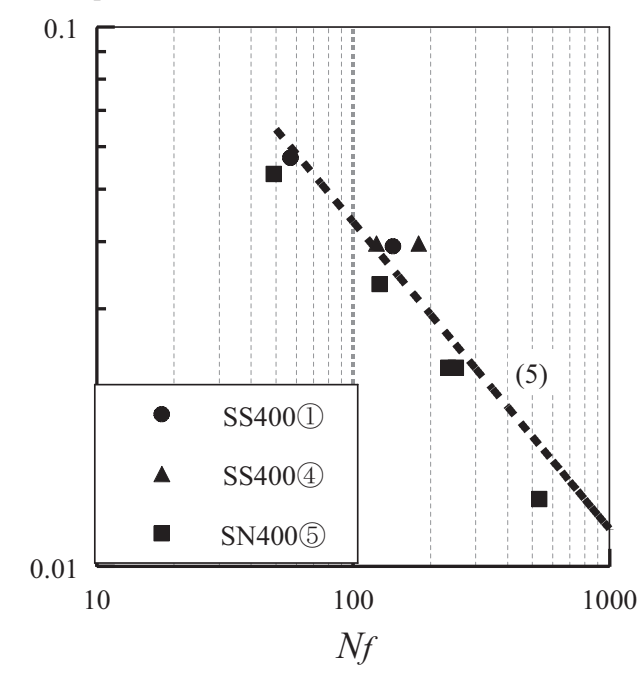

図9定振幅載荷で行った実験結果と Manson-Coffin 式

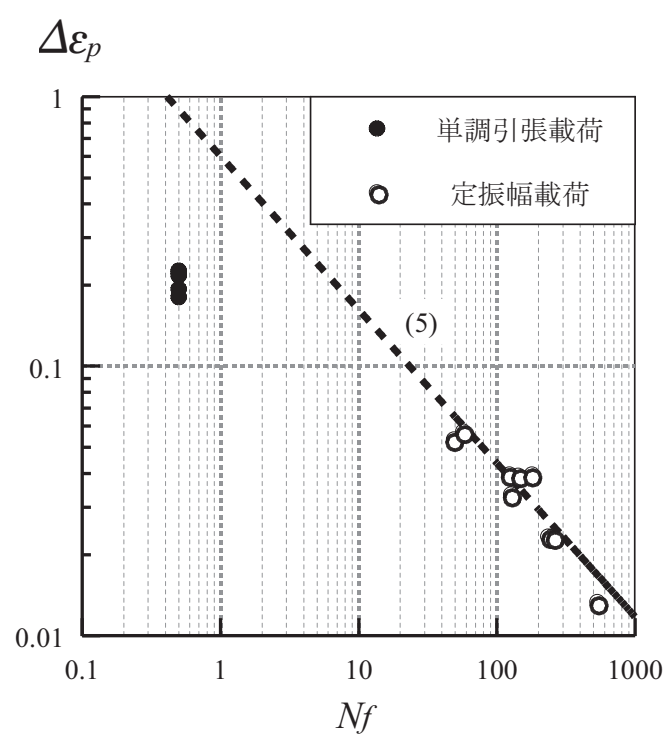

図11 単調引張載荷の結果と Manson-Coffin 式(5)の対応

D

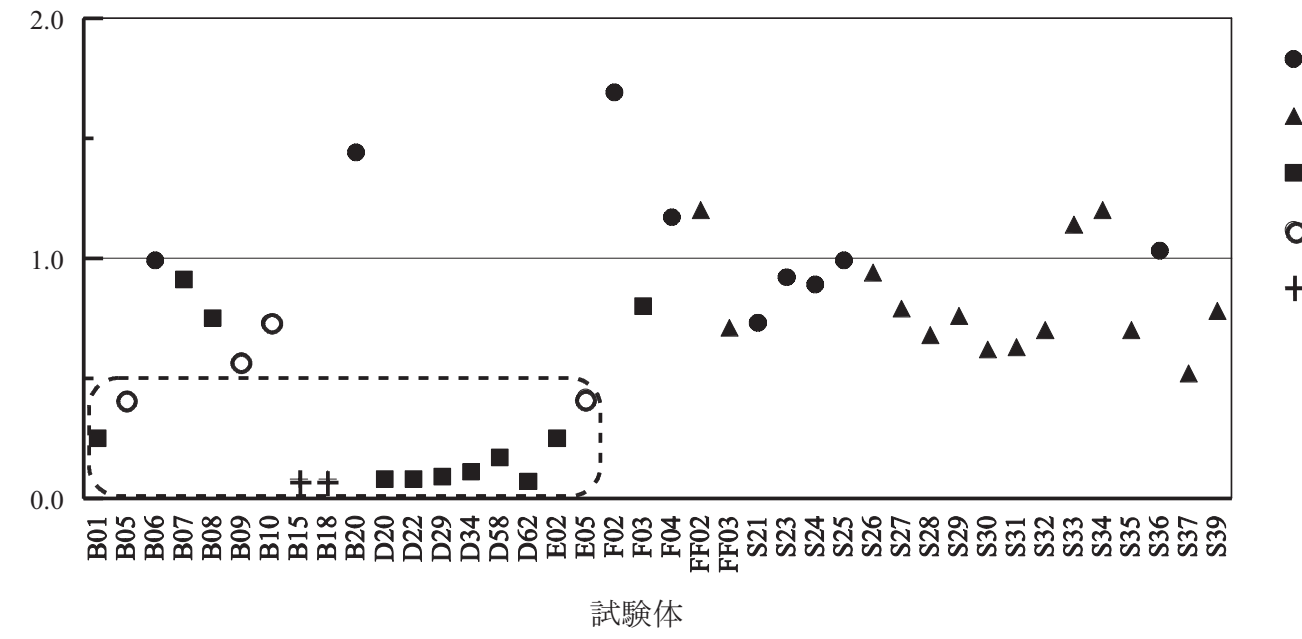

定振幅載荷

オフセット載荷

- 定振幅 $\rightarrow$ 引張載荷

○ 漸増振幅 $\rightarrow$ 引張載荷

+ ランダム $\rightarrow$ 引張載荷

図10 Miner 則による累積損傷の評価 


\section{3 評価法の比較}

本節では、3 章で示した骨格曲線に着目した評価法と、4.2 節で 示した Manson-Coffin 式と Miner 則による評価法の比較を行う。な お、骨格曲線に着目した評価法では誤差が等価累積塑性歪倍率ある いは累積塑性歪倍率で表され、Manson-Coffin 式と Miner 則による 評価法では誤差は累積損傷度で表されることから、両者を直接比較 することはできない。そこで本研究では、誤差を塑性歪振幅 $2 \%$ で の繰り返し数に換算して比較する。

まず骨格曲線に着目した評価法では、式(4)を用いた場合実験結 果との誤差は、累積塑性歪倍率で表した誤差 $e r \eta_{T}$ を単調引張載荷を 行った試験体の累積塑性歪倍率 $\eta_{0}$ で除した值 ${ }^{2} \eta \eta_{T} / \eta_{0}$ で表される。こ のうち ${ }_{\mathrm{N}} \eta_{\mathrm{T}}$ に降伏歪 $\varepsilon_{y}$ を掛けた值が累積塑性歪で表した誤差である。 これを塑性歪振幅(全振幅)の 2 倍で除すことで、繰り返し数として 誤差が表される。

$$
{ }_{e r} N_{s k l}={ }_{e r r} \eta_{T} \cdot \varepsilon_{y} /(2 \cdot 0.02)
$$

なお、誤差には骨格曲線も含まれると考えた場合には、式(4)にお いて右辺に代入する值にも誤差が含まれることになり誤差が一義的 に定まらなくなるが、ある程度塑性歪履歴を与えた後に小さな振幅 での定振幅載荷を行った場合には、一般に骨格曲線は現れないこと から、誤差には骨格曲線は含まれないものとする。一方、 Manson-Coffin 式と Miner 則による評価法による誤差 $\mathrm{er}_{\mathrm{m}} N_{\mathrm{m} m \mathrm{~m}}$ は、式(6) による誤差に式(5)により求めた塑性歪振幅 $2 \%$ での破断までの繰り 返し数を掛けることで求まる。

骨格曲線に着目した評価法による誤差 $e N_{s k l}$ と Manson-Coffin 式と Miner 則による評価法による誤差 ${ }^{2} N_{m c m}$ を比較し、図 12 に示す。正 の誤差は評価值が実験結果を上回ったこと、すなわち塑性変形能力 を過大評価したことを、負の誤差は過小評価したことを表す。骨格 曲線に着目した評価法の方が Manson-Coffin 式と Miner 則による評 価法に比べ誤差が小さいことがわかる。また、Manson-Coffin 式と Miner 則による評価法では載荷履歴により過大評価あるいは過小評 価側に誤差が偏るのに対し、骨格曲線に着目した評価法では載荷履 歴の違いによる影響も見られない。

Manson-Coffin 式および Miner 則による累積損傷の評価は、疲労 から低サイクル疲労まで幅広い振幅域を統一的に評価できるのに対 し、骨格曲線およびバウシンガー部における歪での評価は、塑性歪 が生じることが前提となっており、疲労の領域には適用できない。 その反面、一方向載荷をべースとしていることから、繰り返しによ る累積歪みが極めて小さく単調載荷に近いような場合にも適用でき る点が特徴である。大振幅での繰り返し回数が極めて少ないだけで なく、場合によっては繰り返し変形を受ける前に破断することもあ る耐震問題を扱う上では、骨格曲線およびバウシンガー部による評 価が有効である。

\section{5. 結論}

一般構造用鋼材 SS400 と建築構造用鋼材 SN400 を対象に、載荷 履歴をパラメーターとした小型要素試験体の軸方向繰り返し載荷実 験を行い、破断に至るまでの変形性能の評価を行った。あわせて、 一般に繰り返し載荷を受ける鋼材の変形能力評価法として用いられ

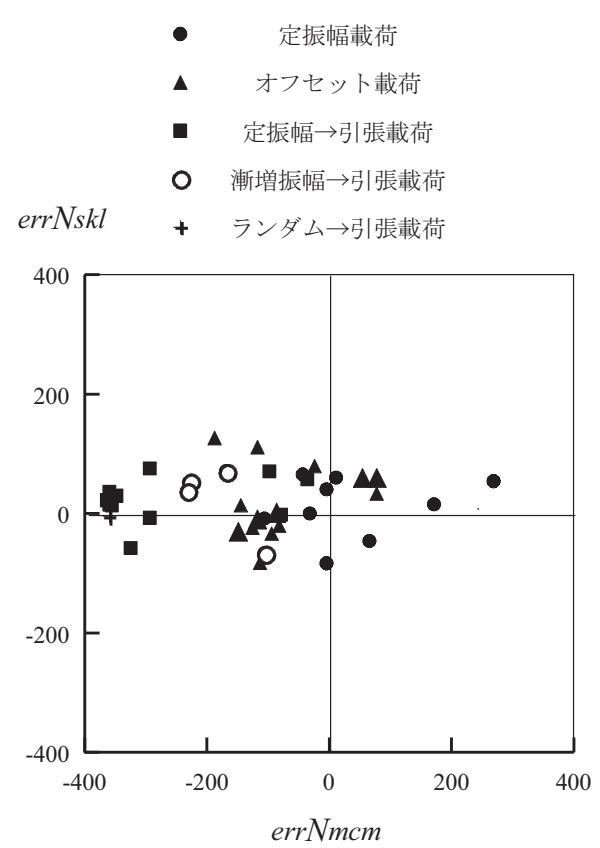

図12 評価法による誤差の比較

ている Manson-Coffin 式および Miner 則による評価も行った。得ら れた結論を以下にまとめる。

1)任意の載荷履歴のもとで軸方向繰り返し載荷を受ける鋼材が破断 するまでのエネルギー吸収能力と、引張側骨格曲線での吸収エネル ギーの間には、式(3)で表される関係がみられる。

2)破断するまでの変形能力を累積塑性歪倍率で表すと、鋼材のエネ ルギー吸収能力の直接的な表現である式(3)同様、式(4)で表すこと ができる。

3)Manson-Coffin 式および Miner 則による累積損傷の評価では、歪 振幅が非常に大きい場合、寸なわち単調引張載荷に近いような場合 には累積損傷をかなり低く評価する。これは、既往の極低サイクル 疲労寿命に関する研究でも指摘されている現象であるが、累積損傷 の評価の基となる定振幅下での破断に至るまでの繰り返し数 $N_{i}$ につ いて、塑性変形能力の限界を一様伸び相当で考えた場合には、歪振 幅が非常に大きな領域で予測できないことも一因である。

4)骨格曲線に着目した評価法と、Manson-Coffin 式と Miner 則によ る評価法では、骨格曲線に着目した評価法の方が Manson-Coffin 式 と Miner 則による評価法に比べ誤差が小さい。また、Manson-Coffin 式と Miner 則による評価法では載荷履歷により過大評価あるいは過 小評価側に誤差が偏るのに対し、骨格曲線に着目した評価法では載 荷履歷の違いによる影響も受けにくい。

5)Manson-Coffin 式および Miner 則による累積損傷の評価は、疲労 から低サイクル疲労まで幅広い振幅域を統一的に評価できるのに対 し、骨格曲線およびバウシンガー部における歪での評価は、塑性歪 が生じることが前提となっており、疲労の領域には適用できないが、 繰り返しによる累積歪みが極めて小さく単調載荷に近いような場合 にも適用できる。大振幅での繰り返し回数が極めて少ないだけでな く、場合によっては繰り返し変形を受ける前に破断することもある 耐震問題を扱う上では、骨格曲線およびバウシンガー部による評価 が有効である。 


\section{謝辞}

本研究における実験の一部は、元東京工業大学大学院生小林亜希 さんの修士課程における研究として行ったものである。

\section{参考文献}

1)秋山 宏: 建築物の耐震極限設計 第 2 版, 東京大学出版会, 1987 2)秋山 宏: エネルギーの釣合に基づく建築物の耐震設計，技報堂出版，1999 3)中込忠男, 見波 進, 深沢 隆, 新井 聡, 大野京子 : 柱梁接合部の脆性 破壊に及ぼす柱軸力の影響に関する破壊力学的検討, 日本建築学会構造系 論文集 第 486 号, pp.125-132，1996.8

4)桑村 仁，松本由香，武谷政國：熱間成形および冷間成形角形鋼管の脆性 破壊，日本建築学会構造系論文集 第 494 号，pp.129-136，1997.4

5)秋山 宏, 山田 哲, 松本由香, 松岡三郎, 大竹章夫, 杉本浩一：実大柱梁接 合部の試験温度による延性破壊一脆性破壊遷移，日本建築学会構造系論文 集第 522 号, pp.105-112, 1999.8

6) S.S. Manson, Behavior of materials under conditions of thermal stress, NASA TND, 2933, 1954

7) L.F. Coffin JR., N.Y. Schenectady, A study of the effect of cyclic thermal stresses on a ductile metal, Transactions of the ASME,pp.931-950, 1954,8

8) Milton A. Miner, Santa Monica, Cumulative Damage in Fatigue, Journal of Applied Mechanics, pp. A159-A164, 1945.9

9) 日本鋼構造協会 : 鋼構造物の疲労設計指針・同解説，技法堂出版，1993
10)嶋田 勝紀、小茂鳥 潤、清水 真佐男：極低サイクル疲労における Manson-Coffin 則の適用性と累積損傷，日本機械学会論文集(A 編), 53 巻 491 号, pp.1178-1185, 1986,7

11)中込忠男, 李 建 : 繰返し力を受ける SM490A 鋼の疲労性に関する研究, 日本建築学会構造系論文集 第469 号, pp.127-136, 1995.3

12)加藤勉, 青木博文, 山内泰之: 引張 - 圧縮繰り返し荷重を受ける鋼素材の 挙動に関する実験的研究，日本建築学会大会学術講演梗概集，pp. 803-804, 1970.9

13) 日本建築学会：建築物の耐震性能評価手法の現状と課題 - 限界耐力計算. エネルギー法・時刻歴応答解析-, 2009.2

14)山田 哲, 鄭 景洙, 吉敷祥一: 繰り返し荷重を受ける鋼部材と鋼材の損傷 の関係，日本建築学会構造系論文集 第 603 号,pp.139-146, 2006.5

15)山田 哲, 今枝知子, 岡田 健: バウシンガー効果を考慮した構造用鋼材の 簡潔な履歴モデル，日本建築学会構造系論文集 第 559 号， pp.225-232, 2002.9

16)秋山 宏, 高橋 誠, 石 軍: 繰り返し曲げを受ける円形断面鋼棒の終局エ ネルギー吸収能力，日本建築学会構造系論文集，第 475 号，pp.145-154, 1995.9

17)遠藤達雄, 松石正典, 光永公一, 小林角市, 高橋清文 : 「Rain Flow Method」 の提案とその応用，九州工業大学研究報告(工学), No.28, pp.33-62, 1974.3

18)舘石和雄, 判治 剛, 南 邦明: 極低サイクル疲労領域における変動振幅 ひずみ下の低サイクル疲労寿命予測モデル、土木学会論文集, No.773，I 69, pp.149-168,2004.10 